\title{
THE PERCEPTION OF VR OF THE TOURISTS VISITING CHOSEN CULTURAL FACILITIES IN GDAŃSK
}

\author{
BARTOSZ KORINTH, ${ }^{1}$ ZHARAS BERDENOV, $^{2}$ SERGEY V. PASHKOV, ${ }^{3}$ \\ JAN A. WENDT ${ }^{4}$ \\ 1 Gdańsk University \\ Faculty of Oceanography and Geography \\ e-mail: bartosz.korinth@dzielo.pl \\ 2 Eurasian National University \\ Faculty of Natural Sciences \\ e-mail: berdenov.87@mail.ru \\ 3 North Kazakhstan State University \\ Faculty of Mathematics and Natural Sciences \\ e-mail: sergp2001@mail.ru \\ 4 Gdańsk University \\ Faculty of Oceanography and Geography \\ e-mail: jan.wendt@ug.edu.pl
}

\section{JEL CODES}

KEYWORDS

ABSTRACT
Z30, Z32, O33

VR, virtual reality, e-tourism, cultural attractions

E-tourism is meeting more and more tourists' needs these days. It is primarily connected with using the Internet as a main tool of contacting the tourist. Therefore, the aim of this study is to collect data concerning the way in which virtual space is perceived by tourists and whether or not it has a possibility of influencing the business in question in the near future. 250 tourists - 138 of whom are Polish and 123 come from abroad - visiting given cultural facilities have been subjected to analysis. The author has chosen to use a diagnostic poll method, that is a standardized survey questionnaire, prepared in Polish, English, German and Russian.

\section{Introduction}

These days, new technologies, which have a very broad reach in terms of many aspects of everyday life, start to play a more and more prominent part in our lives (Tarr, Warren, 2002). They are being used in construction, industry, transportation, communication and, finally, in tourism (Hobson, Williams, 1995; Williams, Hobson, 1995; Olearnik, 2015) whereas the latter is particularly important for this paper. Every time academic publications mention the use of new technologies in 
tourism, they usually associate them with IT (Guttentag, 2010). At present the influence of such technologies can be observed in hotel industry, travel agencies, heritage tourism (Mosaker, 2001) and airlines (Kalecińska, 2013), where their use can be equalled with a fast development of an industry.

Furthermore, new technologies are highly influential in terms of the development of e-tourism (Arnold, 2005; Pujol, 2011), which is a non-traditional form of tourism, the main spectrum of activity of which is the Internet and everything connected with it. Therefore, we could draw a conclusion that the development of new technologies is a basis for the development of e-tourism, and simultaneously it has prompted the increase of its influence in recent years.

Before leaving on a journey, tourists mainly make use of Internet resources and new technologies, which have appeared because of those. The function and demand for it makes us think about the way in which all of those elements directly influence a tourist and their perception.

The aim of the study is to analyze in detail the perception of VR of the tourists visiting chosen by the author cultural facilities: the Gdańsk Historical Museum, the National Museum in Gdańsk and the European Solidarity Centre. The main assumption of the analysis is based on the supposition that VR aids the development of tourism and is an important element of the communication with the tourist these days.

The following questions include the main research demands:

1. Have the tourists ever used virtual tours?

2. After using those, would they be more eager to visit a given place?

3. Do the tourists think that virtual tours are needed in tourism industry?

4. Do they use virtual tourism tools and what do they think about those?

The fact that is relatively interesting (from the researcher's perspective) is that the source literature has not yet started to deal with the perception of VR of the tourists visiting Poland.

\section{Theoretical considerations}

The noticeable increase of influence of information extraction and trade making via the Internet are one of the most prominent technological trends in tourist industry (Markiewicz, 2013). Source literature indicates on informatization being one of the most crucial factors influencing the modern development of the industry in question. Virtual reality plays an important part in this trend. In source literature, it is described as real life transferred to virtual life via computer methods (Durydiwka, Duda-Gromada, 2011). The international literature refers to virtual reality as a 3D-constructed environment, in which a virtual tourist can move around and interact with it (Guttentag, 2010). A broader definition is presented by S. Bryson (1996), who relates virtual reality to a direct interaction of a virtual tourist with virtual tourist objects. The transfer of real life into a virtual one, enriched by the above mentioned interactions, allows to construct a unique trade and marketing tool in tourist industry (Grzegorczyk, Majewski, Wróblewski, 2014; Disztinger, Schlögl, Groth, 2017; Rainoldi et al., 2018). 
Source literature also presents the earlier studies regarding the subject in question. Above all, behavior of the consumers in virtual and expanded reality has been analyzed (Augument Reality). The results have indicated that the virtual reality's opportunities, which are provided to the consumers, in a positive way influence the structure of market demand (including tourist industry) and enable and make the process of decision making of a potential tourist faster (Berbeka, 2016). A different source analyzes tourists' opinions regarding virtual sightseeing, that is virtual presentation of places existing in reality (Burdea, Coiffet, 2003). The crucial point for those studies has been a declaration of websites' acquaintance by the tourists and indication of virtual tools to be used by almost all of the respondents (Stepaniuk, 2011).

\section{Material and methods}

250 tourists have been subjected to the study, 138 of whom were from Poland and 123 - from abroad. The study was being conducted from $26^{\text {th }}$ June 2017 to $15^{\text {th }}$ September 2017, when one can observe the increase of tourist activities in Polish cultural facilities, which is conditioned by, among other things, climate and changing weather conditions in the course of the year (Stasiak, 2011).

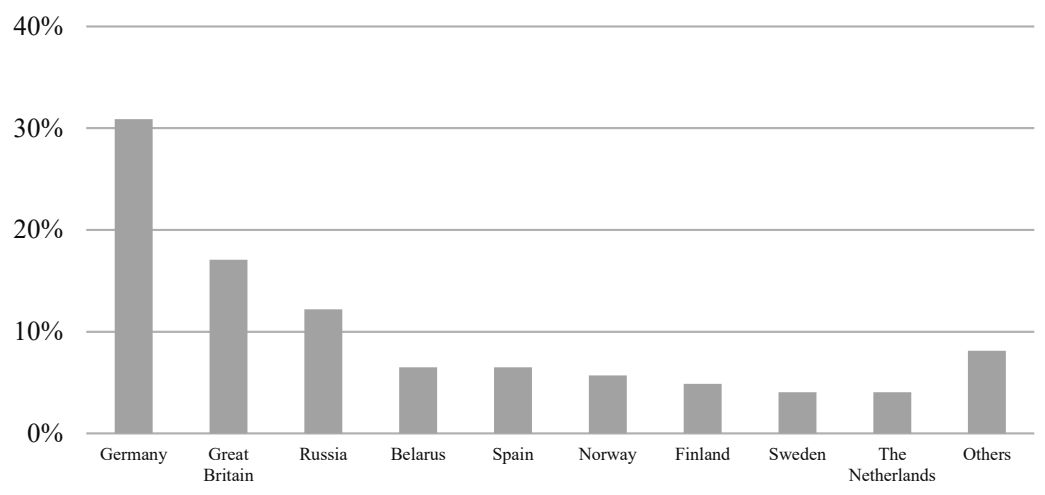

Figure 1. The percentage of foreign respondents per country

Source: own study.

In the case of the latter of the elements provided, one can notice the variety of tourists' countries of origin (fig. 1). The vast majority of the tourists visiting Poland was from Germany (more than $30 \%$ of the respondents). More than $10 \%$, in turn, have arrived in Poland from the UK and Russia. There were less than 10\% of tourists from Japan, the USA, Malta, Austria, Italy, Latvia, Slovakia, Ukraine or Luxembourg.

The age of the respondents is vital from the perspective of the study's aims (fig. 2). As one may observe, the largest group was in the age 18-24 (30\%). 25\% of the respondents were 25-39 years old, whereas $20 \%$ of them $-40-59$ years old. The respondents of those age ranges constitute the most numerous group. The least numerous group is, on the other hand, comprised of people aged 0-17 or more than 80 (the latter constitutes less than $5 \%$ of all the respondents). As we can notice, 
the most numerous group is composed of people from 18 to 59 years old, who will constitute a target group for cultural facilities' offers during the following holiday seasons. It is worth mentioning that the age of the respondents can heavily influence their answers. When analyzing the issue of perception of VR, it is important to remember that people in this age range are more likely to be acquainted with technological developments in comparison to middle-aged people.

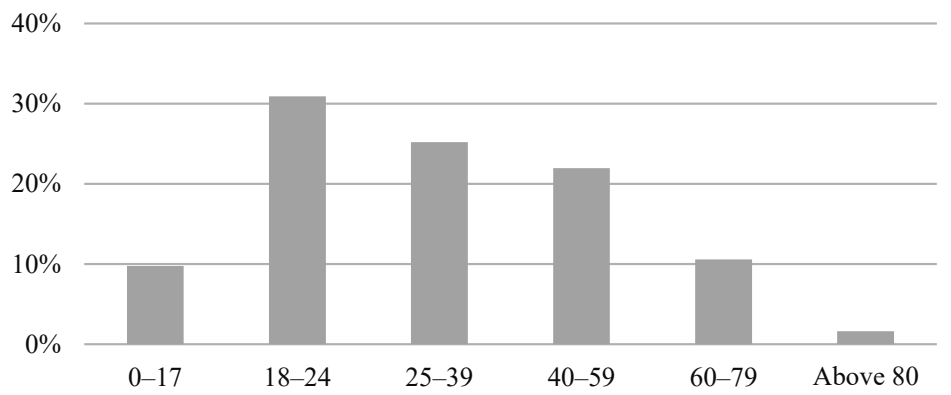

Figure 2. The percentage of the respondents both from Poland and abroad, divided according to their age.

Source: own study.

The questionnaire was based on all the elements mentioned by E. Babbie (2008) in his discussion about the structure of a research process. It was composed of questions, $90 \%$ of which were closed questions, and $10 \%$ - open, multiple choice questions. The study also used literature on the subject showing the development of VR tools in the tourism industry and its marketing.

\section{Results}

Undoubtedly, VR starts to play an important role in tourism and in the future, its development will condition the e-tourism's place on the market along with all of those tools, which are based on the newest technologies. Therefore, there was included a question in the questionnaire, very important from the author's perspective, which allowed one to measure whether the tourists visiting given cultural facilities have ever used virtual tours (fig. 3).

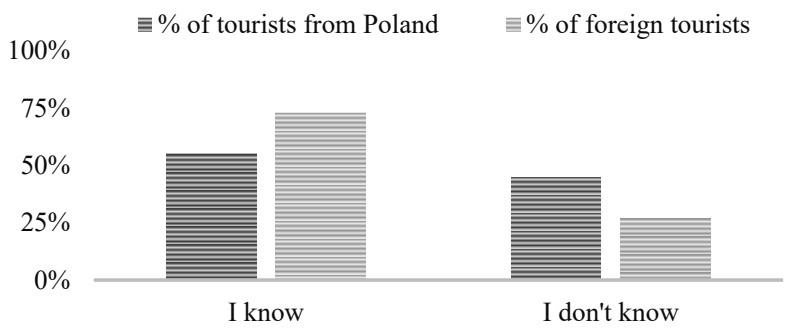

Figure 3. Knowledge of virtual tours, according to the tourists taking part in the survey Source: own study. 
There is a relatively small dominance of Polish tourists $(55 \%)$ when it comes to people who have used virtual tours in the past. The results concerning tourists from abroad look somewhat different, as $73 \%$ of the respondents provided an affirmative answer. When analyzing this part of the study, one can observe that both virtual tours, in the case of the tourists from Poland and those from abroad, constitute an important factor influencing their perception of VR.

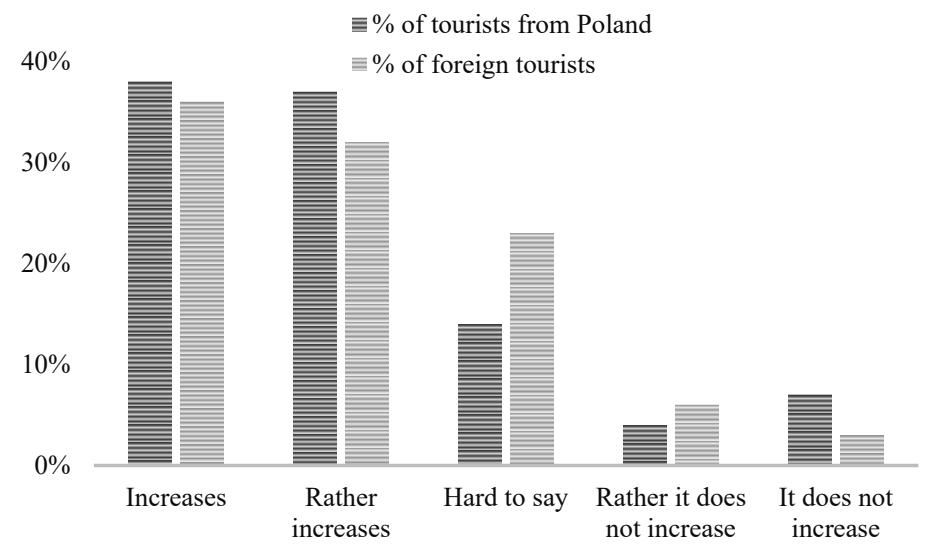

Figure 4. The increase of motivation to visit a given place after taking a virtual "trip", according to the tourists taking part in the survey

Source: own study.

The next question included in the questionnaire is treated by the author as a leading question, which allows people who have had contact with virtual tours to express their opinion by describing their motives for visiting a particular place. Therefore, the following question was included in the questionnaire: "Would you be more eager to visit a certain place after having a virtual tour?" (fig. 4).

Basing our assumptions on the results of the study, it can be stated that a vast majority of the respondents, both from Poland and abroad, have provided an affirmative answer, claiming that after a virtual tour they would more likely visit a certain place (2/3 of the respondents). The least numerous group were the people who stated that virtual tours do not influence or rather do not influence their eagerness to visit a certain place. Also, a small proportion of the respondents were not able to indicate whether virtual tourism affects their interest in visiting an actual place, or not (12\% tourists from Poland and 20\% tourists from abroad gave that answer).

When analyzing the issue of the VR's perception of the tourists, it was vital to note the needs of studying the group (fig. 5). The term 'need' here means the motivational force that prompts one to a certain activity which leads to change of undesired circumstances they find themselves in. This definition of the term "need" is provided by, among others, Abraham Maslow (2009) and Leon Niebrzydowski (1999). 


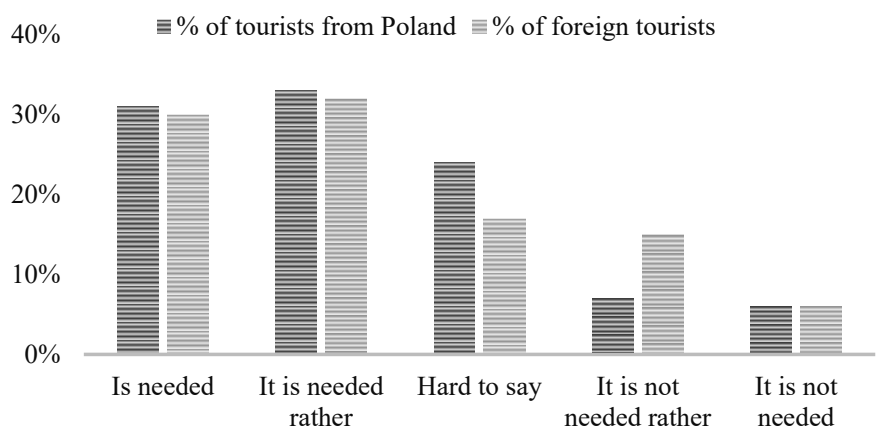

Figure 5. Number of tourists who stated the importance and need for virtual sightseeing

Source: own study.

As the gained data confirms, the majority of tourists, both from Poland and abroad, believe that virtual sightseeing is either needed or rather needed (approximately $60 \%$ in both groups). Drawing upon the notion of the "need, one must conclude that virtual sightseeing is perceived as an important element supporting museums and the whole tourism industry. As a matter of fact, the role of modern technology is essential when it comes to shaping the right type of behavior among various visitors".

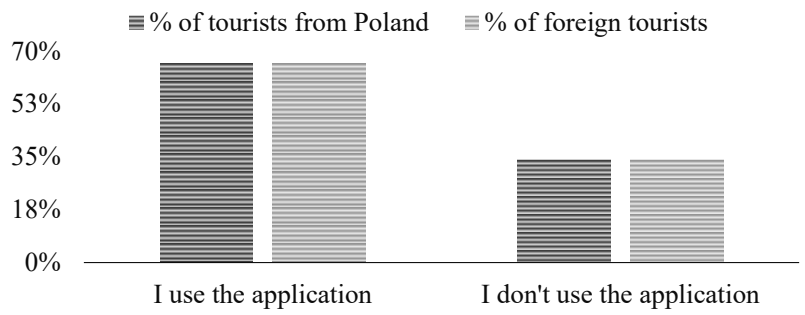

Figure 6. A percentage comparison of tourists' using the Google Street application before the actual journey Source: own study.

In one of the surveys people were asked whether they use Google Street before travelling to a given place (fig. 6). As the survey revealed, a large percentage of interviewees from Poland uses the application before actually going to and reaching their destination. Similar results were gained among tourists from abroad. A negative response was given by one third of the respondents. Therefore, one may conclude that Google Street is indeed an important tool that is being used by various tourists who travel round Poland. 


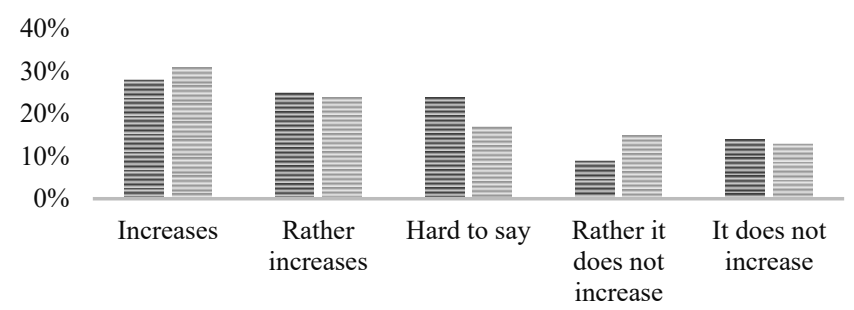

Figure 7. The results of the study devoted to the issue of feeling safer after using the Google Street application Source: own study.

Another question that was asked may be seen as the key one. That is, whether "visiting" and seeing a place via Google Street assures the tourists of their safety when visiting cultural institutions in a country (fig. 7). The analysis of those results lets us attest that a relatively big number of people points at the usefulness of the Google Street application when it comes to strengthening their feelings of safety before the actual journey. Such an answer was given by $30 \%$ of tourists from abroad and slightly above $25 \%$ of Polish tourists. As regards the latter group, one may notice similar percentages in such responses as "rather yes" or "difficult to say". The least popular choice was the one stating the disutility of the application before our journey.

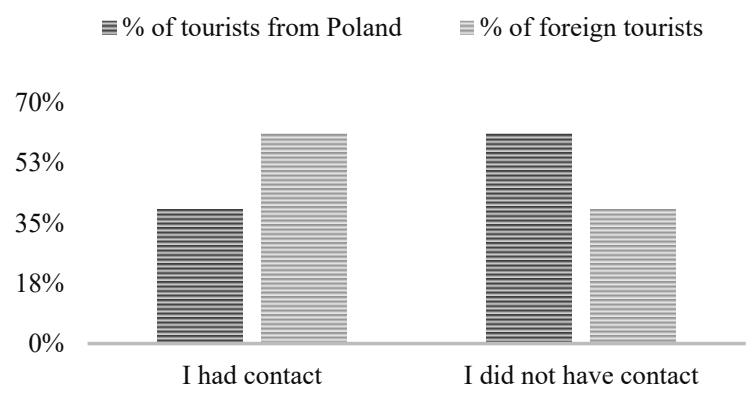

Figure 8. The number of tourists who came into contact with googles used for "entering" the virtual reality Source: own study.

Google Street is certainly an essential part and tool in the development of e-tourism. Hence, it is self-evident that its usage may determine how a place is virtually perceived by tourists both from home and abroad. All the study groups were asked whether they had any contact with similar tools (fig. 8). As can be seen in the material presented, there is a certain disparity when it comes to both groups. In the case of tourists from abroad, almost $60 \%$ of the respondents has had some sort of contact with such a tool, whereas Polish tourists constitute a small number. Such a result may be due to the countries' respective economies, that is, they mainly come from stronger, western economies. 


\section{Discussion}

In the last few years, issues connected with the influence of virtual space on various human activities have been brought up in world literature. On the other hand, in Poland this issue seems relatively new, discussed mostly in specialist literature which deals with technological implications of virtual tools. In comparison to West-European literature, the investigated aspect is rarely referred to in connection to tourism industry. Therefore, in Polish journals, one may notice a complete lack of publications regarding the topic of VR in tourism and this lacuna should be filled in the next few years (Kečkeš, Tomičić, 2017). The research carried out ought to cover not only mobile operational systems (the base of VR) (Kounavis, Kasimati, Zamani, 2012), but also open up new contexts in the developing tourism industry. Even though the industry is beginning to function in virtual space, it is also experienced by the tourists (Włodarczyk, 2009).

One needs to highlight that in source literature virtual tourism is more often defined as a chance to pass on information regarding cultural heritage in a simulated world (Guerra, Pinto, Beato, 2015), the world that is not limited as it is in the case of traditional tourist activities. There are no geographical, social or economic barriers in such a world. This chance lets cultural institutions use their own tools in order to provide the best touristic offer and to extend their services so that the contact with a potential tourist is much easier. One example of such a procedure may be the virtual journey through Palace of Regaleria (Adrião, 2013), a Portuguese residence which is one of the World Heritage sites.

Another significant issue is examining the virtual space in tourism itself, its implications and perspectives for future development. The definition of "touristic space" is perceived in various ways, depending on the individual needs of a concrete author. What is more, the changes that are taking place in the modern world require us to alter the existing definitions, to extend them and to include other aspects, such as touristic activity in the virtual world. This particular aspect could greatly influence the perception of the whole touristic space, which is investigated by a number of disciplines, one of them being geography (Wendt, 2011; Ilieş, Wendt, 2015).

One cannot help but notice a certain shortage of studies devoted to the tourists' perception of virtual space. When examining the source literature, the author came upon but one publication that explicitly referred to the issue discussed in this work. However, the author of the publication places virtual reality in tourism, taking into account only its economic aspects. He overlooks the social ones completely (Howell, Hadwick, 2017).

It seems that the studies of virtual space and tourism showed the need to develop more tools which may be used by numerous tourists visiting cultural institutions. Such a need arises from the popularity of Google tools and the Google Street application which, beyond any doubt, contribute to the feeling of security/safety before leaving for one's destination.

\section{Conclusions}

As can be deduced from the literature, VR, initiated at the end of the last century, has undergone significant evolution in the last ten years. It has moved from the category of niche tools and tourism 
to the classic marketing tools of the largest museums and historical tourism facilities as well as heritage tourism. VR is nowadays present as one of the essential elements of marketing and planning and selection of a tourist destination.

Based on the tests carried out, several regularities can be confirmed. Today, a significant percentage of visitors know and use virtual journeys. Traveling in the VR version affects the potential decisions related to the choice of destination. The view of the objects visited in Virtual Reality is one of the factors determining the tourists' visit in the actual tourist trip. It can be assumed that at this stage of the development of VR techniques virtual touring is already an indispensable element in the touristic industry and will influence its development. As is clear from the research carried out, a relatively large group of people not only knows but in practice uses VR tools both in marketing of tourist facilities and in planning of tourist trips.

\section{References}

Adrião, V. (2013). Quinta da Regaleira; Sintra, História e Tradição. Lisboa: Book Dinapress.

Arnold, D. (2005). Virtual tourism: a niche in cultural heritage. In: M. Novelli (ed.), Niche tourism: Contemporary issues, trends, and cases (pp. 223-231). New York: Elsevier.

Babbie, E. (2008). Podstawy badań społecznych. Warsaw: Wydawnictwo Naukowe PWN.

Berbeka, J. (2016). Wirtualna i rozszerzona rzeczywistość a zachowania konsumentów. Studia Ekonomiczne, 303, 84-101. Bryson, S. (1996). Virtual reality in scientific visualization. Communications of the ACM, 5 (39), 62-71.

Burdea, G.C., Coiffet, P. (2003). Virtual reality technology. New York: John Wiley \& Sons.

Disztinger, P., Schlögl, S., Groth, A. (2017). Technology acceptance of virtual reality for travel planning. In: R. Schegg, B. Stangl (eds.), Information and Communication Technologies in Tourism 2017 (pp. 255-268). Cham: Springer.

Durydiwka, M., Duda-Gromada, K. (2011). Między autentycznością a kreacją - tendencje i przyczyny zmian w przestrzeni turystycznej In: M. Durydiwka, K. Duda-Gromada (eds.), Przestrzeń turystyczna. Czynniki, różnorodność, zmiany. Warsaw: Wydawnictwo Poligrafia.

Grzegorczyk, A., Majewski, J., Wróblewski, S. (2014). Innowacje w przemyśle spotkań. Warszw: WSP.

Guerra, J.P., Pinto, M.M., Beato, C. (2015). Virtual reality - shows a new vision for tourism and heritage. European Scientific Journal, 1, 49-54.

Guttentag, D.A. (2010). Virtual reality: Applications and implications for tourism. Tourism Management, 31, 637-651.

Hobson, J.S.P., Williams, A.P. (1995). Virtual reality: a new horizon for the tourism industry. Journal of Vacation Marketing, 1 (2), 125-136.

Howell, D., Hadwick, A. (2017). Does Virtual Reality Have a Place in Travel? London: EyeforTravel.

Ilieş, A., Wendt, J.A. (2015). Geografia turystyczna. Podstawy teorii i zagadnienia aplikacyjne. Gdańsk: Wydawnictwo AWFiS.

Kalecińska, J. (2013). Nowe technologie w branży turystycznej. Warsaw: Ecorys.

Kečkeš, A.L., Tomičić, I. (2017). Augmented Reality in Tourism - research and applications overview. Interdisciplinary Description of Complex Systems 2 (15), 157-167.

Kounavis, C.D., Kasimati, A.E., Zamani, E.D. (2012). Enhancing the Tourism Experience through Mobile Augmented Reality: Challenges and Prospects. International Journal of Engineering Business Management, 4, 1-6.

Maslow, A. (2009). Motywacja i osobowość. Warszawa: Wydawnictwo Naukowe PWN.

Markiewicz, E. (2013). Rola społeczności wirtualnej w kształtowaniu produktu na rynku turystycznym. Folia Turistica, 29, 189-203.

Mosaker, L. (2001). Visualising historical knowledge using virtual reality technology. Digital Creativity, 12 , 1-11.

Niebrzydowski, L. (1999). Psychologia ludzkich potrzeb, aspiracji i możliwości. Łódź: Krajowa Rada Self-Esteem. 
Olearnik, J. (2015). Innowacje $w$ turystyce - ich charakter i obszary poszukiwań. Wrocław: Akademia Wychowania Fizycznego.

Pujol, L. (2011). Realism in Virtual Reality applications for Cultural Heritage. International Journal of Virtual Reality, 3 (10), 41-49.

Rainoldi, M., Driescher, V., Lisnevska, A., Zvereva, D., Stavinska, A., Relota, J., Egger, R. (2018). Virtual Reality: An Innovative Tool in Destination' Marketing. The Gaze: Journal of Tourism and Hospitality, 9, 53-68.

Stasiak, A. (2011). Współczesna przestrzeń turystyczna, In: M. Durydiwka, K. Duda-Gromada (eds.), Przestrzeń turystyczna. Czynniki, różnorodność, zmiany. Warsaw: Wydawnictwo Poligrafia.

Stefanik, M., Kamel, M. (2013). Muzea i wystawy interaktywne w Polsce - współczesna atrakcja turystyczna. Turystyka kulturowa, 8, 5-9.

Stepaniuk, K. (2011). Wirtualne zwiedzanie w opinii internautów w Polsce. Ekonomia i Zarządzanie, 3, 75-80.

Tarr, M.J., Warren, W.H. (2002). Virtual Reality in behavioral neuroscience and beyond. Nature, 5, 1089-1092.

Wendt, J. A. (2011). Zarys geografii turystycznej. Gdańsk: Wydawnictwo Uniwersytetu Gdańskiego.

Williams, A.P., Hobson J.S.P. (1995). Virtual reality and tourism: fact or fantasy? Tourism Management, 6 (16), $423-427$.

Włodarczyk, B. (2009). Przestrzeń turystyczna. Istota, koncepcje, determinanty rozwoju. Łódź: Wydawnictwo Uniwersytetu Łódzkiego.

\section{PERCEPCJA PRZESTRZENI WIRTUALNEJ PRZEZ TURYSTÓW ODWIEDZAJĄCYCH WYBRANE INSTYTUCJE KULTURY W GDAŃSKU}

\section{SŁOWA KLUCZOWE \\ STRESZCZENIE}

VR, rzeczywistość wirtualna, e-turystyka, walory kulturowe

E-turystyka zaspokaja w ostatnich latach coraz więcej potrzeb turystycznych. Związana jest ona przede wszystkim z wykorzystaniem internetu jako głównego narzędzia kontaktu z turystą. Dlatego za cel badań przyjęto uzyskanie informacji jak przestrzeń wirtualna postrzegana jest przez turystów i czy ma ona szansę wpłynąć na analizowaną branżę w perspektywie niedalekiej przyszłości. Badaniem objęto łącznie 250 turystów odwiedzających wybrane instytucje kultury, z czego 138 pochodziło z Polski, zaś 123 przyjechało z zagranicy. W pracy posłużono się metodą sondażu diagnostycznego w postaci zestandaryzowanej ankiety sporządzonej przez autora w języku polskim, angielskim, niemieckim i rosyjskim. 